\title{
26 Hinos Homéricos
}

Carlos Leonardo Bonturim Antunes

Resumo: Uma tradução poética de 26 Hinos Homéricos, seguindo a solução de Carlos Alberto Nunes para reproduzir o ritmo do hexâmetro dactílico grego em lingua portuguesa.

Palavras-chave: binos boméricos, tradução poética, Carlos Alberto Nunes.

Apresento aqui uma tradução poética para 26 Hinos Homéricos, na qual empreguei a solução métrica de Carlos Alberto Nunes, usada em suas traduções da Ilíada e da Odisseia, para recriar o hexâmetro datílico grego em Português. ${ }^{12}$

Sua solução é bastante conhecida, mas resumo-a mesmo assim: Nunes emprega um verso de 16 sílabas, datílico, com acentos na primeira, quarta, sétima, décima, décima terceira e (como não poderia deixar de ser) décima sexta sílaba. Com isso, ignoram-se algumas particularidades do verso grego, a saber: i) a possibilidade de contração das sílabas breves dos dáctilos em uma sílaba longa; ii) a presença de (ao menos uma) cesura. Porém, o verso oferece bastante espaço para que se trabalhe o texto e possui uma sonoridade singular, fazendo com que seja, a meu ver, uma solução bastante boa para a tradução de hexâmetros dactílicos empenhada em imitar seu metro/ritmo. ${ }^{3}$

1 [Nota do Organizador: sobre o procedimento de Carlos Alberto Nunes, ver neste volume artigo "11 poemas de Propércio (I, 1-11) traduzidos com o verdadeiro dístico elegíaco de Péricles Eugênio da Silva Ramos", de João Angelo Oliva Neto].

2 Também empreguei a solução de Nunes nas traduções que apresento em Ritmo e Sonoridade na Poesia Grega Antiga (2011).

3 Outra solução interessante, tendo em vista a aproximação rítmica, é a que Marcelo Tápia (2012) sugere em sua tese de doutoramento, na qual ele se permite substituir dáctilos por troqueus (que devem, na verdade, ser lidos como espondeus). Para um panorama das soluções mais variadas já empregadas para traduzir o hexâmetro dactílico em Português, recomendo o artigo de Rodrigo Tadeu Gonçalves. 
Como exemplo ilustrativo, cito o verso 49 do primeiro canto da Ilíada em sua tradução:

Do ar / co / de / pra / ta / co / me / ça a ir / ra / diar / -se um / clan / gor / pa / vo / ro / so.

Sendo uma tradução poética, minha preocupação principal ao traduzir estes hinos para o Português foi a de construir um texto eufônico, buscando não só uma cadência agradável de sons, mas também vocábulos que se encadeassem de modo natural dentro do ritmo escolhido.

\section{Hino Homérico 6, a Afrodite}

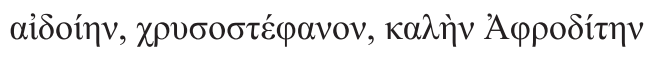

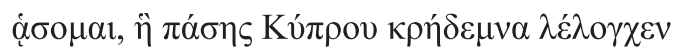

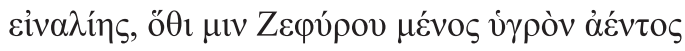

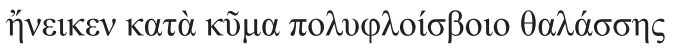

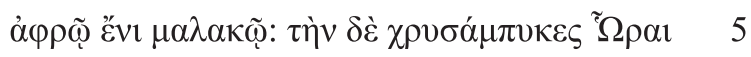

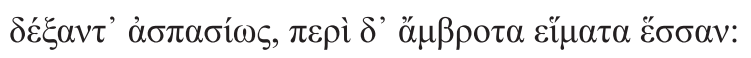

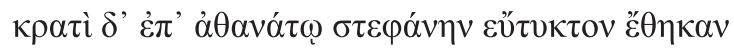

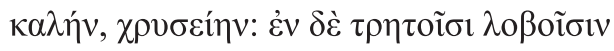

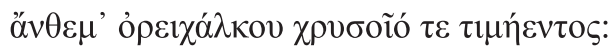

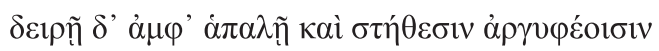

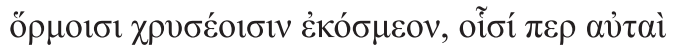

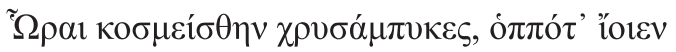

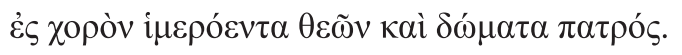

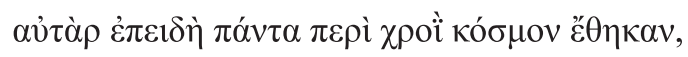

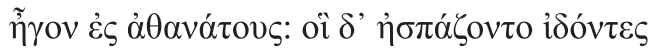

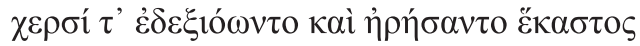

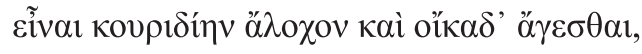

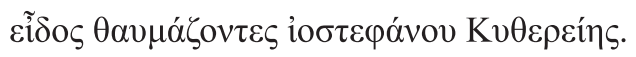

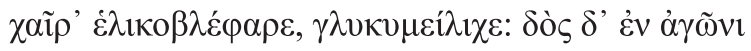

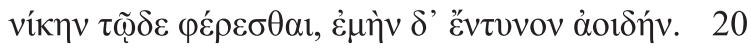

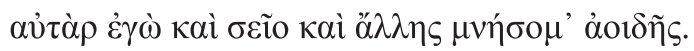

Canto a formosa Afrodite, de láureas douradas e augusta, Que tem por lote as cidades muradas de Chipre marinha Toda, onde a úmida força do Zéfiro, tendo soprado, Trouxe-a por cima das ondas do mar de multíplices vozes Dentro de espuma macia. As Horas de frisos dourados A receberam gentis e a envolveram com veste ambrosina. Sobre a cabeça imortal colocaram-lhe láureas bem-feitas, Belas, lavradas em ouro. Nos lóbulos já perfurados, Elas puseram-lhe enfeites de ouro estimado e oricalco E lhe adornaram seus seios argênteos e o tenro pescoço Com amuletos dourados, os quais são as joias que as próprias Horas de frisos dourados costumam vestir quando vão Rumo à mansão de seu pai para a dança adorável dos deuses. Logo, depois de lhe ornarem sua forma de modo completo,

Elas levaram-na aos deuses eternos que a vendo a acolheram, Dando-lhe as mãos e rogando poder conduzi-la pra casa, Cada um dos deuses, na forma de sua legítima esposa, Tanto Citéria ${ }^{4}$ das láureas violáceas os tinha espantado. Salve, senhora dos olhos furtivos, do doce que vence! Dá-me vencer o presente certame e equipar-te em canção! Ora de ti eu irei me lembrar e de uma outra canção.

4 Uso "Citéria" em vez de "Citereia" por questões métricas. 


\section{Hino Homérico 8, a Ares}

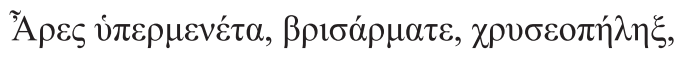

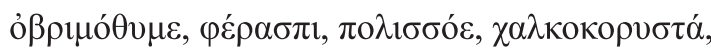

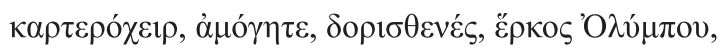

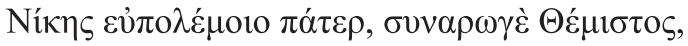

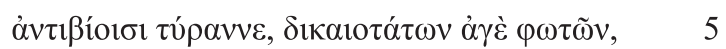

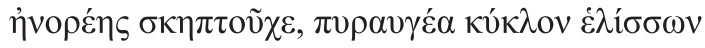

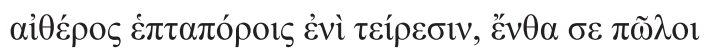

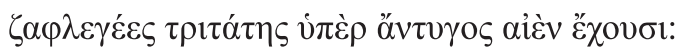

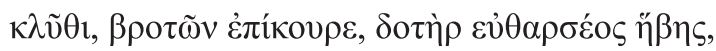

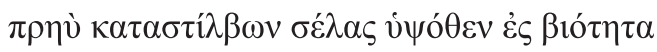

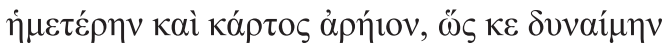

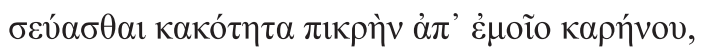

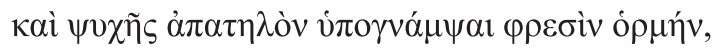

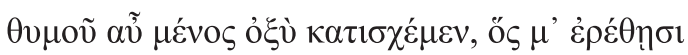

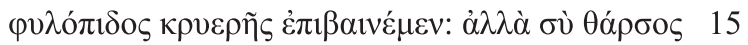

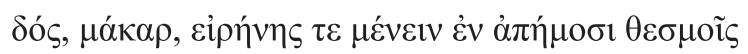

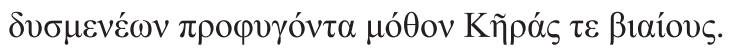

Ares fortíssimo, mestre de bigas, do elmo dourado, Bravo, escudeiro, guardião de cidades, das armas de bronze, Muro do Olimpo, incansável, lanceiro potente, mão forte, Pai da vitória em combates guerreiros, aliado de Têmis, Líder dos homens honestos, tirano das forças contrárias, Dono do cetro viril, que circulas tua esfera de fogo Junto dos sete caminhos celestes, nos quais teus cavalos Ígneos te levam além da terceira divisa do céu, Auxiliador dos mortais, doador de uma audaz juventude, Ouve-me! Do alto me manda teu raio gentil sobre a minha Vida e concede-me força guerreira, de modo que eu possa Afugentar essa vil covardia da minha cabeça E suprimir as pulsões enganosas que vêm da minha alma. Freia o furor aguçado do meu coração, que me faz Ir pelas trilhas geladas da guerra, mas dá-me a coragem De me manter junto às leis salutares da paz, ó ditoso, Para evitar as disputas, a raiva e as Queres violentas.

\section{Hino Homérico 9, a Ártemis}

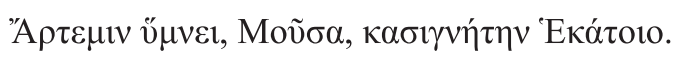

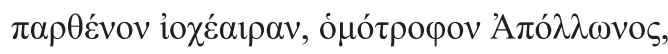

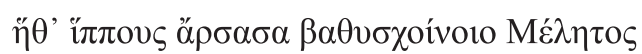

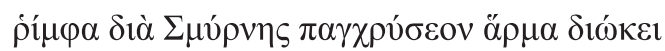

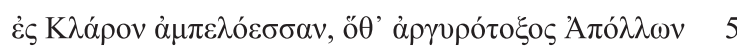

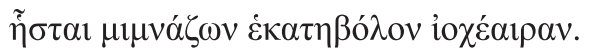

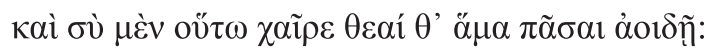

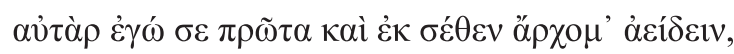

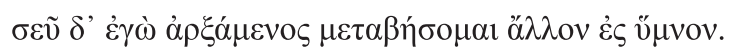

Canta a respeito de Ártemis, Musa, da irmã do flecheiro, Virgem arqueira, criada da mesma maneira que Apolo, Aos seus cavalos do Meles juncoso ela dá de beber E ágil conduz o seu carro dourado através de Esmirna Rumo às videiras de Claros, local em que Apolo se senta Com o seu arco de prata aguardando a flecheira longínqua. Salve, senhora e demais divindades com esta canção! Canto primeiro a respeito de ti e contigo eu começo! E começando contigo uma nova canção cantarei!

\section{Hino Homérico 10, a Afrodite}

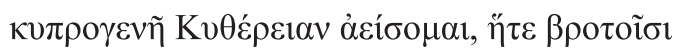

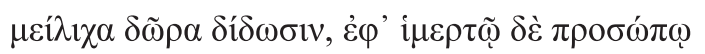

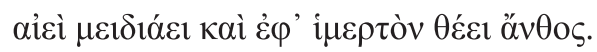

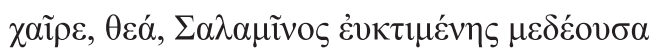

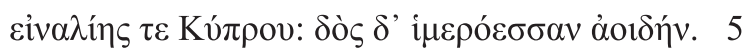

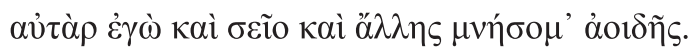

Eu cantarei a nativa de Chipre, Citéria, ${ }^{5}$ que aos homens Dá seus presentes gentis, com sorrisos no rosto adorável Sempre e adorável também sendo o brilho que cobre a sua tez. Salve, deidade, que tens Salamina bem-feita em tua guarda e Chipre banhada no mar! Para mim, dá uma amável canção! Ora de ti eu irei me lembrar e de uma outra canção.

$5 \quad$ Vide nota 3. 


\section{Hino Homérico 11, a Atena}

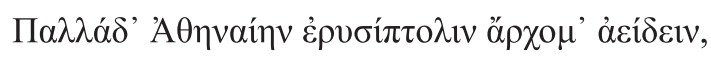
$\delta \varepsilon เ v \eta ́ v, ~ \hat{~}$

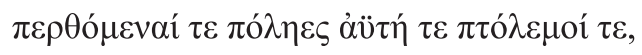

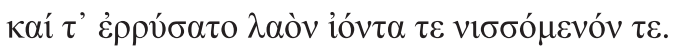

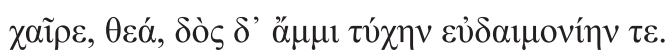

Canto a respeito de Palas Atena, guardiã de cidades, Dama terrível, amante com Ares dos feitos de guerra, Da espoliação de cidades, dos gritos de guerra e das lutas. Ela é quem salva os soldados que vão e conseguem voltar. 5 Salve, senhora! Concede-nos felicidade e fortuna!

\section{Hino Homérico 12, a Hera}

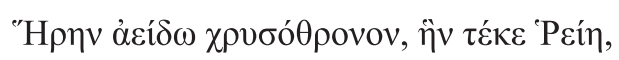

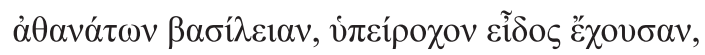

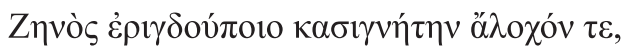

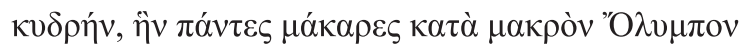

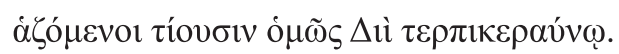

Hera de trono dourado, nascida de Reia, é quem canto, Régia entre os deuses eternos, suprema na forma que tem. Ela é a irmã e a esposa de Zeus, trovejante sonoro, A gloriosa a quem todos os deuses ditosos do Olimpo Magno veneram, até Zeus que tem seu deleite com raios.

\section{Hino Homérico 13, a Deméter}

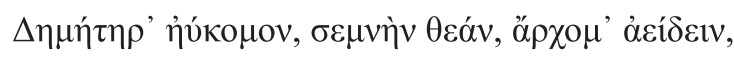

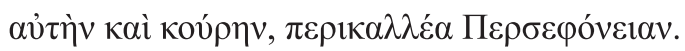

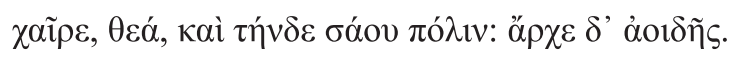

Canto Deméter de belos cabelos, deidade espantosa, Ela e sua filha, Perséfone, bela de todas as formas.

Salve, deidade! Protege esta pólis e guia o meu canto!

\section{Hino Homérico 14, à Mãe dos Deuses}

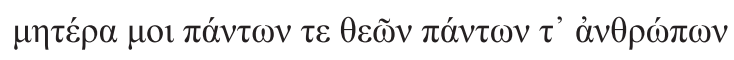

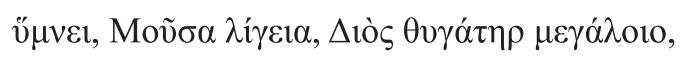

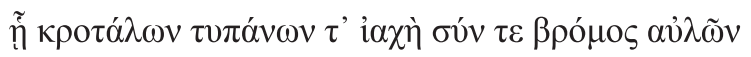

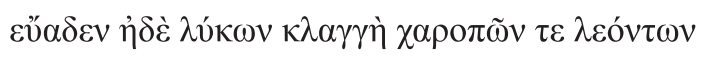

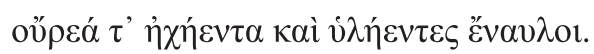

Canta-me a mãe, genitora de todos os deuses e homens, Musa nascida de Zeus grandioso, com tua voz clara. Ela se apraz com o som do tambor, do chocalho e dos aulos, Com o clangor de leões de olhos rútilos e de lupinos Sobre montanhas ecoantes e leitos lenhosos de rios. Salve, senhora e demais divindades com esta canção!

\section{Hino Homérico 15, a Héracles Coração de Leão}

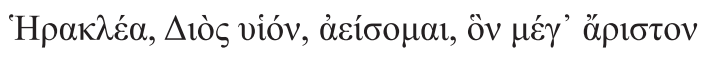

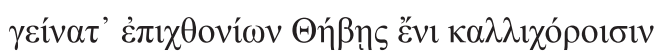

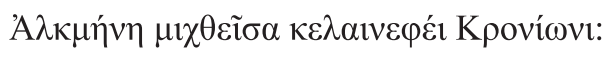

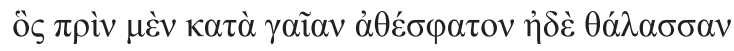

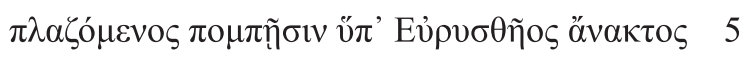

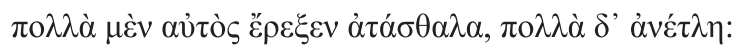
vข̃v $\delta$ '

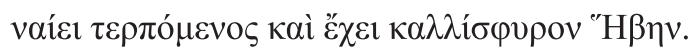

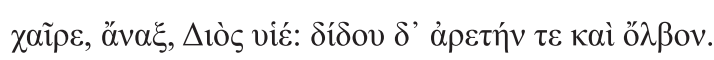

Canto a respeito de Héracles, filho de Zeus, o mais nobre Dentre os terrestres, que em Tebas dos coros amáveis Alcmena, Em união ao Cronida de nuvens escuras, gerou. Ele, quem antes vagava a amplitude do mar e da terra Imensurável por ordens diretas do rei Euristeu, Fez muitos feitos ousados e muito também suportou. Ora ele habita uma bela morada no Olimpo nevado Onde é feliz junto de Hebe com seus tornozelos formosos. Salve, senhor, filho a Zeus! Dá-me prosperidade e excelência! 


\section{Hino Homérico 16, a Asclépio}

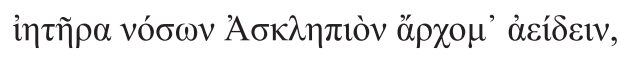

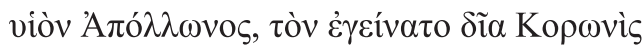

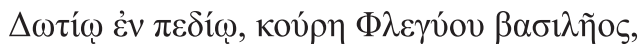
$\chi \alpha ́ \rho \mu \alpha \mu \varepsilon^{\prime} \gamma^{\prime} \alpha \dot{\alpha} v \theta \rho \omega ́ \pi 01 \sigma 1, \kappa \alpha \kappa \tilde{\omega} v \theta \varepsilon \lambda \kappa \tau \tilde{\eta} \rho$ ’ ỏ $\delta v v \alpha ́ \omega v$.

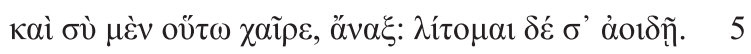

Canto a respeito do médico para doenças, Asclépio, Prole de Apolo, que foi dado à luz pela filha do rei Flégias, Corônis divina, nos prados chamados de Dótios, Júbilo para os humanos, alívio de dores ruins.

5 Salve, portanto, senhor! Faço preces a ti na canção!

\section{Hino Homérico 17, aos Dióscuros}

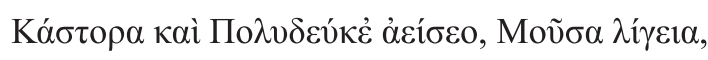

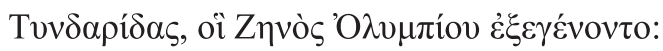

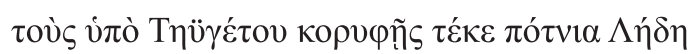

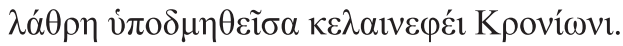

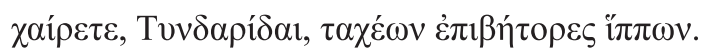

Canta-me Cástor e Pólux, ó Musa, com tua voz clara, Filhos nascidos de Tíndaro e do Olímpico Zeus.

Sob o Taígeto altíssimo Leda senhora os gerou Mando secreto do filho de Crono de nuvens escuras. Salve, Tindáridas, ágeis ginetes de vossos cavalos!

\section{Hino Homérico 18, a Hermes}

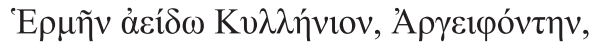

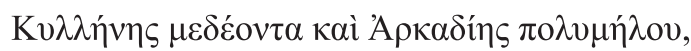

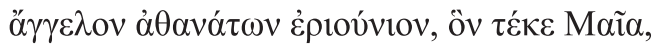

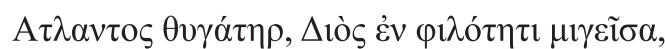

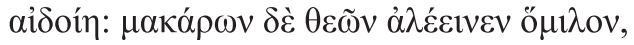

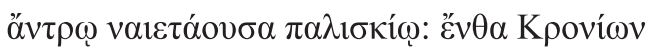

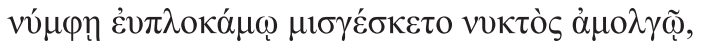

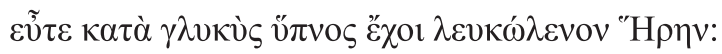

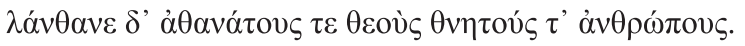

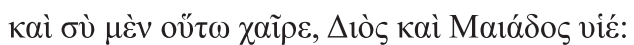

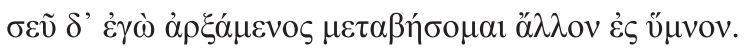

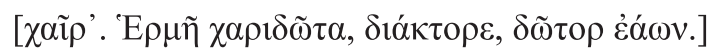

Canto a respeito de Hermes, nascido em Cilene, Argicida, Lorde da Arcádia de fértil rebanho e também de Cilene, Núncio auspicioso dos deuses eternos, gerado por Maia, Filha de Atlas, após ter-se unido com Zeus em amor.

5 Tímida, sempre evitava a assembleia dos deuses ditosos E numa gruta sombria vivia. Foi lá que o Cronida De madrugada se unia co' a ninfa de belos cabelos, Hera dos cândidos braços já pega no sono adoçado. Nenhum dos homens mortais ou dos deuses eternos sabia. Eu te saúdo, portanto, rebento de Zeus e de Maia! Tendo iniciado contigo eu me viro a uma outra canção! Salve, doador de benesses, debens, mensageiro,ó Hermes!

\section{Hino Homérico 20, a Hefesto}

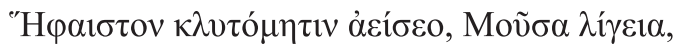

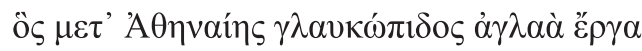

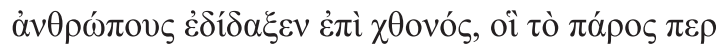

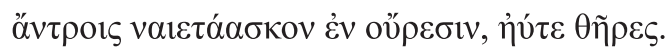

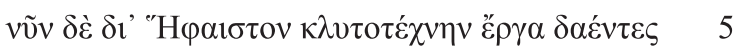

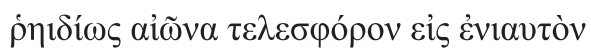

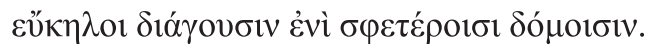

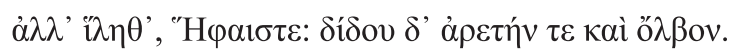

Canta-meHefesto,famosoinventor,Musa,emlímpidavoz. Junto de Atena dos olhos brilhantes pros homens terrestres Ele ensinou seus trabalhos gloriosos aos que antes viviam Dentro de grutas nos montes aos moldes de feras selvagens.

5 Hoje aprendidas as artes de Hefesto famoso artesão, Vivem suas vidas de modo tranquilo e sem dificuldades Dentro de suas moradas ao longo dos anos inteiros. Dá-nos, Hefesto, tua graça, com prosperidade e excelência! 


\section{Hino Homérico 21, a Apolo}

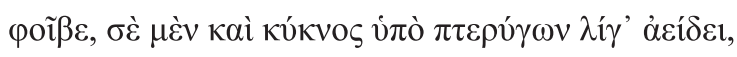

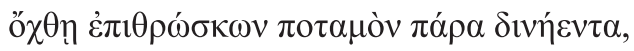

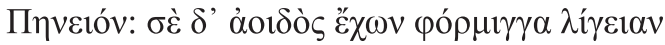

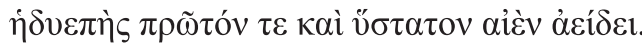

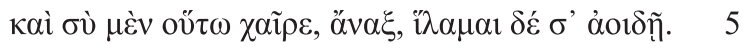

Febo, até o cisne te canta em voz clara, ruflando suas asas Quando alça voo das orlas do rio encrespado, o Peneio, $\mathrm{E}$ a teu respeito o cantor, com a lira de claros acordes, Canta primeiro e por último sempre na voz adoçada. Salve, portanto, senhor! Que eu te agrade com minha canção!

\section{Hino Homérico 22, a Posêidon}

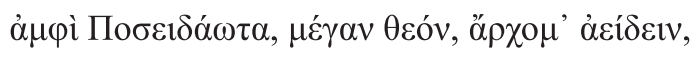

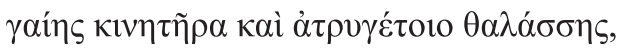

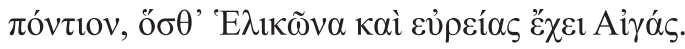

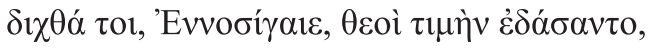

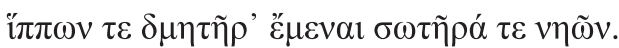

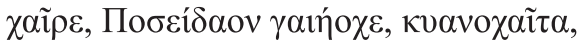

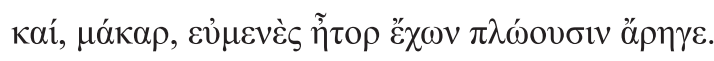

Sobre Posêidon, gigante entre os deuses, começo a cantar, Ele que faz se moverem a terra e o mar infecundo E tem seu mando marinho no Hélicon e no Egeu vasto. Ó Fremidor, os divinos te deram um dúplice ofício: 5 Ser domador de cavalos e ser salvador de navios.

Salve, Posêidon, dos cachos escuros, que a terra chacoalha! Com coração benfazejo, ditoso, protege os marujos!

\section{Hino Homérico 23, ao Superno Cronida}

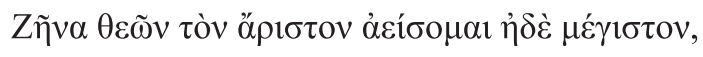

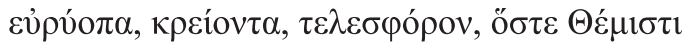

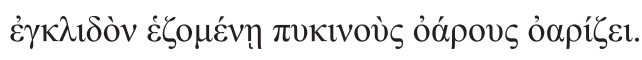

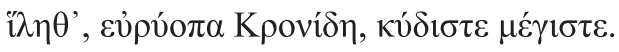

Eu cantarei sobre Zeus, o maior e mais nobre dos deuses, De ampla visão, cumpridor, soberano, que fala palavras Sábias a Têmis enquanto ela senta inclinada ao seu lado. Amplividente Cronida, maior, mais honrado, sê bom!

\section{Hino Homérico 24, a Héstia}

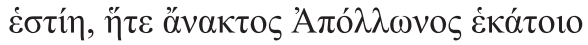

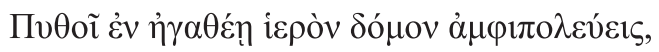

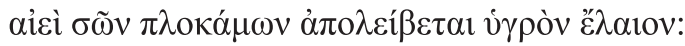

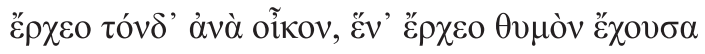

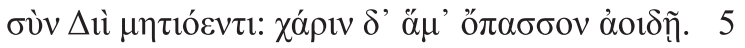

Héstia, que prestas cuidados à casa sagrada de Apolo, Lorde das flechas longínquas, postada na Pito divina, Sempre pingando um azeite suave a partir dos teus cachos, Vem a esta casa munida de um ânimo uno com Zeus Conhecedor e, chegando, traz graça pra minha canção!

\section{Hino Homérico 25, às Musas e a Apolo}

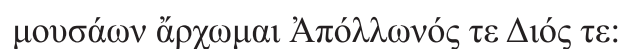

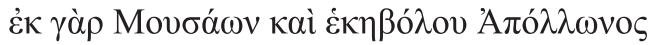

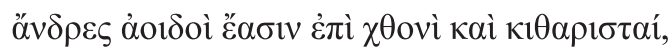

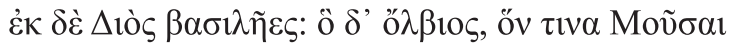

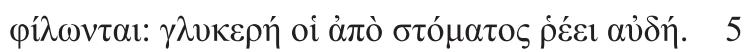

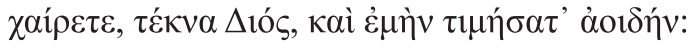

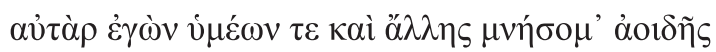

Canto a respeito de Apolo, rebento de Zeus, e das Musas, Pois é por meio do arqueiro distante, de Apolo, e das Musas, Que há sobre a terra liristas e aedos em meio aos humanos, Mas é por Zeus que há monarcas. Feliz é aquele que as Musas Amam e a voz que lhe flui a partir de sua boca é adoçada. Salve, crianças de Zeus! Concedei honra à minha canção! E eu, de vós todos, irei me lembrar e de uma outra canção! 


\section{Hino Homérico 26, a Dioniso}

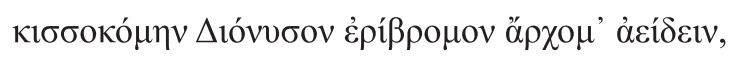

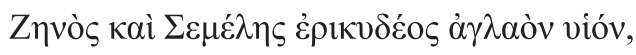

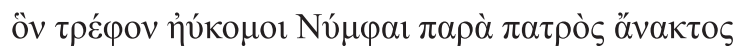

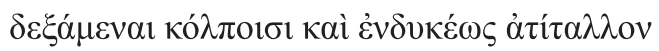

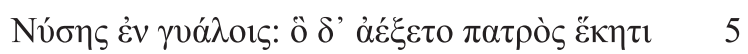

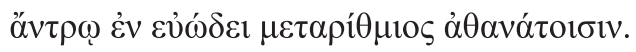

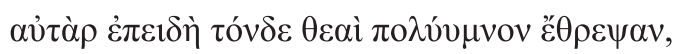
$\delta$ ๆ่̀

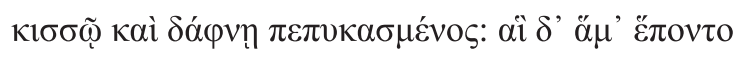

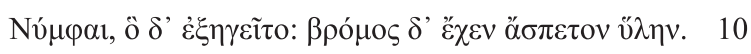

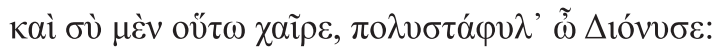

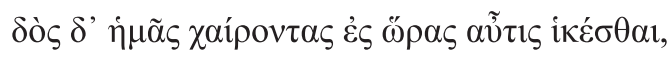

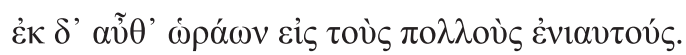

Canto Dioniso, das láureas de vinhas, dos brados sonoros, Filho de Zeus e de Sêmele, muito famoso e esplendente, Alimentado no colo das Ninfas de belos cabelos Que o receberam do lorde, seu pai, e o criaram com zelo 5 Nas reentrâncias de Nisa, onde pela vontade do pai Ele cresceu numa gruta olorosa e contado entre eternos. Mas, quando as deusas o tinham criado pra ser celebrado, Ele se pôs a vagar pelos leitos de rios arvorados Com suas vestes de vinhas e louros e as Ninfas então Foram seguindo-o por guia, seus brados enchendo a floresta. Salve, portanto, Dioniso, ó munido de múltiplas vinhas! Dá-nos chegar novamente para esta estação jubilosos! E ano após ano também para cada estação que vier!

\section{Hino Homérico 27, a Ártemis}

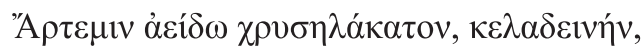

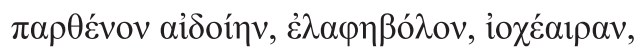

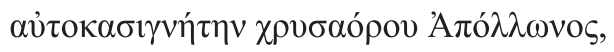

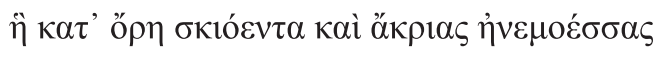

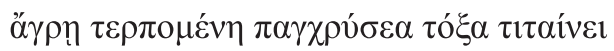

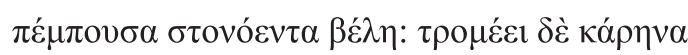

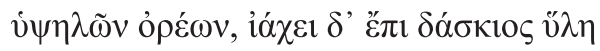

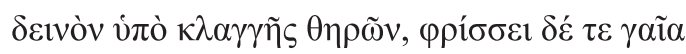

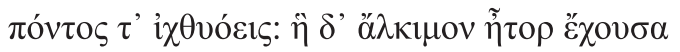

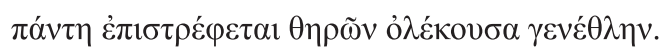

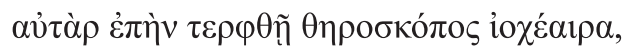

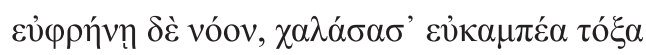

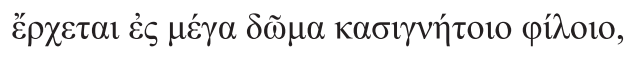

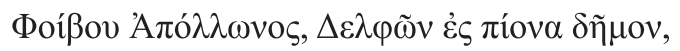

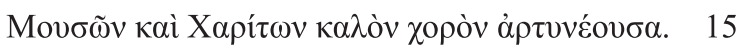

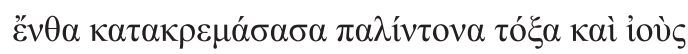

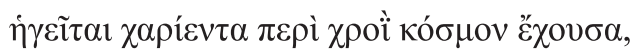

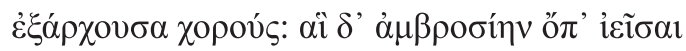

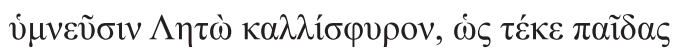

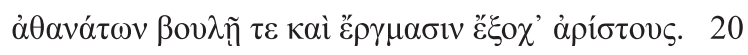

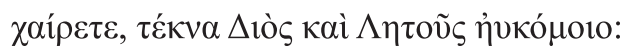

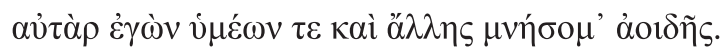

Ártemis de hastes douradas, que clama a caçada, é quem canto, Virgem augusta, que lança suas setas no gamo, flecheira, Ela e não outra é a irmã para Apolo da espada dourada. Sobre as montanhas umbrosas e os cumes cortados por ventos, 5 Saca o seu arco de ouro maciço, alegre ao caçar, E suas flechas doridas atira. Estremecem-se os picos De altas montanhas e as matas cerradas ecoam com gritos Hórridos vindos das feras. A terra é tomada em tremor, Bem como o mar rico em peixes. Mas com coração resoluto Vira-se a todos os lados, matando a linhagem das feras. Quando por fim se contenta a flecheira com sua caçada, Tendo já o ânimo alegre, relaxa o seu arco flexível E vai então para a grande morada do irmão estimado, De Febo Apolo, que fica na terra fecunda de Delfos, Para ordenar a belíssima dança das Graças e Musas.

Lá dependura por fim o seu arco recurvo e suas flechas E então conduz, com a forma alinhada e repleta de graça, Dando o início às danças, enquanto com voz ambrosíaca Canta-se o fato de Leto dos pés graciosos ter tido Filhos supremos em meio aos eternos em mente e em seus feitos. Salve, crianças de Zeus e de Leto de belos cabelos! Ora de vós eu irei me lembrar e de uma outra canção! 


\section{Hino Homérico 28, a Atena}

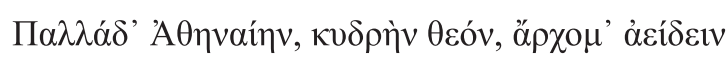

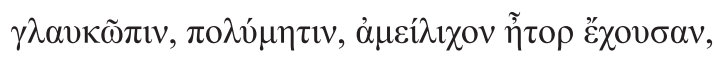

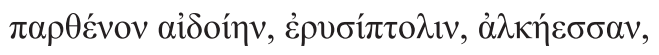

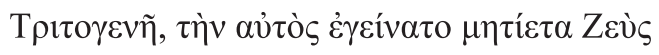

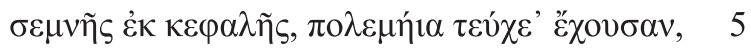

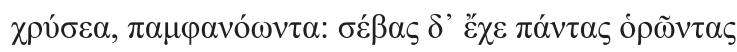

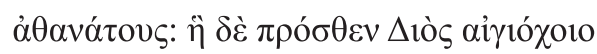

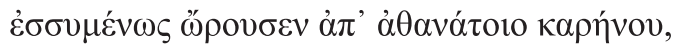

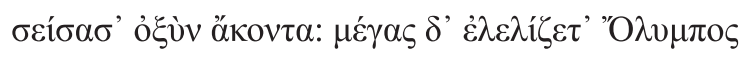

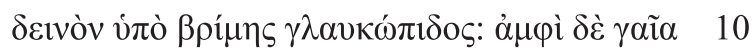

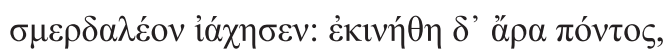

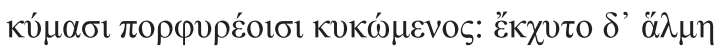

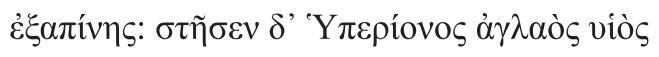

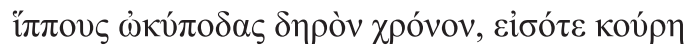

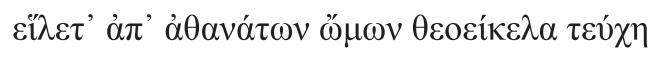

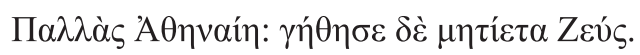

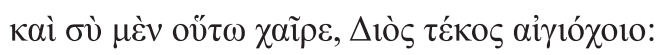

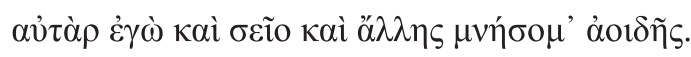

Canto a respeito de Palas Atena, deidade gloriosa

De olhos brilhantes, de planos diversos, de cárdio incansável, Virgem augusta, guardiã de cidades, impávida dama, Filha terceira, que Zeus sabedor deu à luz por si próprio De sua cabeça sagrada, vestida com armas de guerra Áureas e esplêndidas. Maravilharam-se todos os deuses Quando a miraram e Atena saltou da cabeça imortal, Pondo-se cheia de ímpeto em frente de Zeus porta-égide Com sua lança afiada na mão e o Olimpo tremeu Fundo à visão da deidade dos olhos brilhantes. A terra Toda se pôs a gritar com terror. Sobre o mar negras ondas Logo quebraram pra todos os lados e espuma irrompeu Subitamente. O rebento brilhante de Hipérion parou Por um momento os seus ágeis cavalos até que a donzela

Palas Atena tirou dos seus ombros eternos por fim Sua armadura deífica e Zeus sabedor se alegrou. Salve, portanto, donzela nascida de Zeus porta-égide! Ora de ti eu irei me lembrar e de uma outra canção.

\section{Hino Homérico 29, a Héstia}

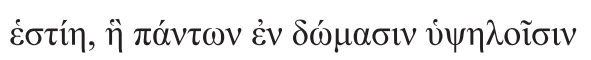

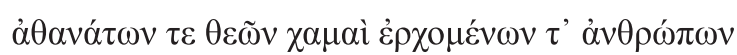

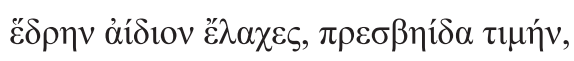

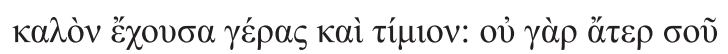

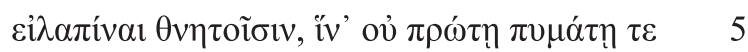

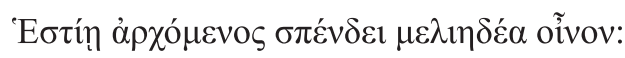

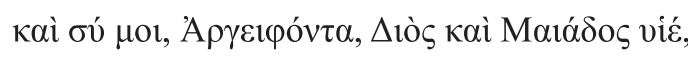

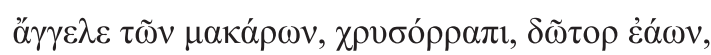

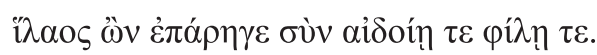

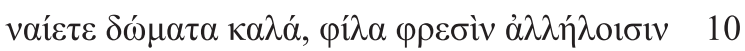

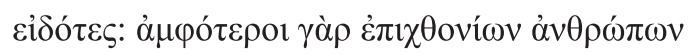

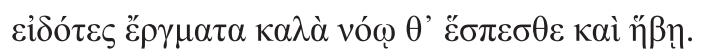

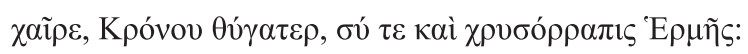

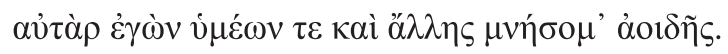

Héstia, que habitas a tua morada no topo do mundo, Deram-te os deuses eternos e os homens que vagam na terra Honras das mais elevadas bem como um assento perene. Bela e honrada é a tua porção. Onde tu não te encontras, Não há banquete pros homens mortais, pois alguém sempre liba A Héstia primeiro e por fim com um vinho de mélea doçura. Já quanto a ti, Argicida, rebento de Zeus e de Maia, Núncio dos deuses, do cetro dourado, doador de benesses, Sê favorável e ajuda-nos com a querida e augusta. Vinde habitar esta casa bonita com mente amistosa Juntos, pois vós conheceis as ações elevadas dos homens Sobre esta terra, a quem vós ajudais com saber e vigor. Salve, nascida de Crono e tu, Hermes do cetro dourado! Ora de vós eu irei me lembrar e de uma outra canção. 


\section{Hino Homérico 30, a Gaia Mãe de Tudo}

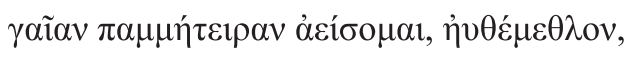

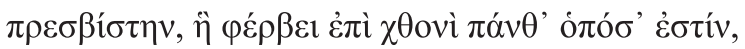

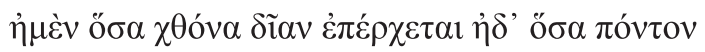

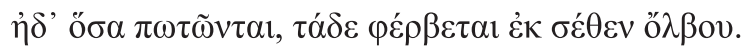

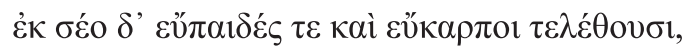

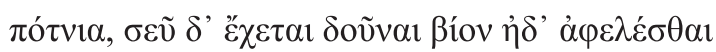

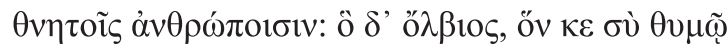

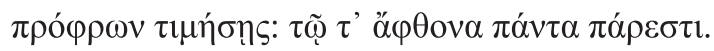

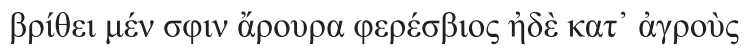

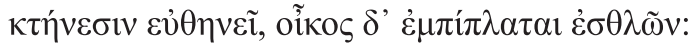

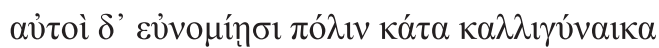

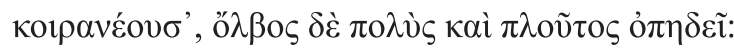

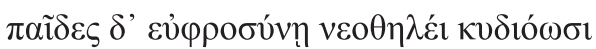

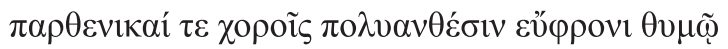

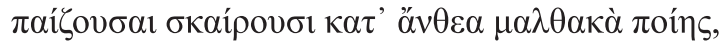

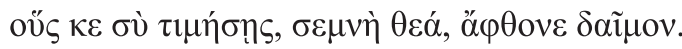

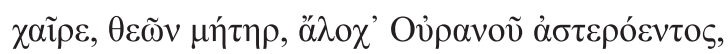

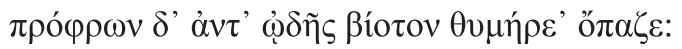

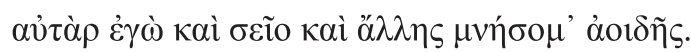

Gaia é quem canto, de bons alicerces, que a tudo gerou, A mais antiga, nutriz para todos que vivem no solo,

Para os que vagam ao longo da terra, os que habitam o mar E os voadores. São todos nutridos na sua fortuna. Tu és quem cede a fartura, senhora, de frutos e filhos, E é dependente de ti dar os meios pra vida ou tirá-los Para os humanos mortais. É feliz quem recebe de ti Esta honraria, benévola. Tudo lhe dá em abundância: Fartos se tornam seus campos, repletos de frutos nutrizes, Os seus rebanhos prosperam e a casa se farta de bens. Tais são os homens que em pólis de belas mulheres, com ordem, Têm o comando. Acompanham-nos grande fortuna e riqueza. Com renovada alegria estão sempre exultando os seus filhos E suas filhas em coros floridos com íntimo alegre Brincam saltando por cima das flores macias dos campos. Tais as tuas honras, augusta deidade, magnânimo nume. Mãe dos divinos, saúdo-te, esposa de Urano estrelado! Benevolente concede ao meu canto alegrar corações. Ora de ti e de uma outra canção eu irei me lembrar!

\section{Hino Homérico 31, a Hélios}

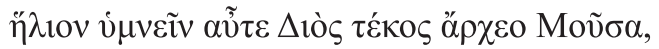

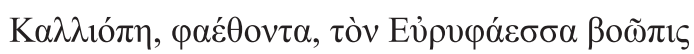

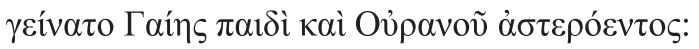

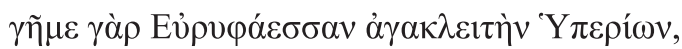

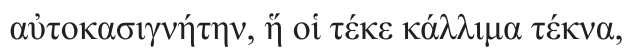

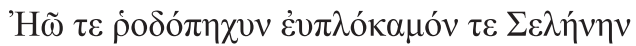

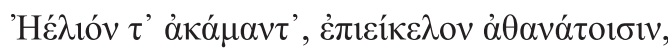

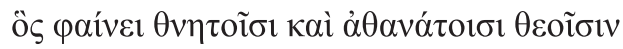

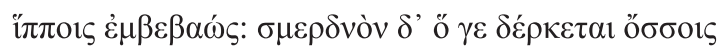

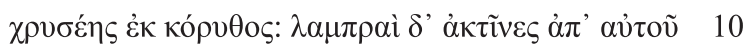

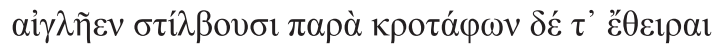

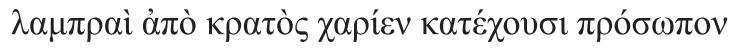

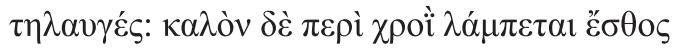

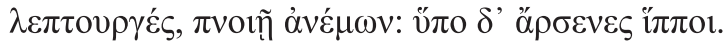

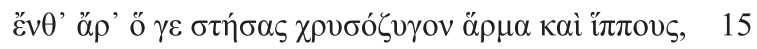

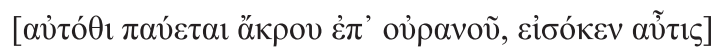

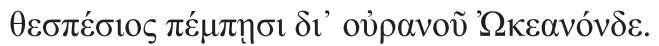

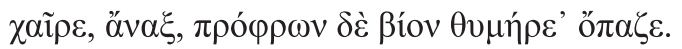

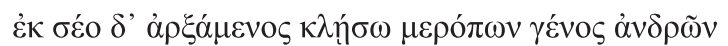

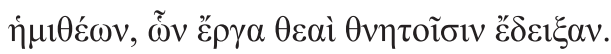

Hélios brilhante, Calíope, Musa nascida de Zeus, Canta-me, a quem Eurifáessa de olhos bovinos gerou Para o rebento de Gaia e de Urano coberto de estrelas, Sim, pois Hipérion glorioso casou-se com sua irmã,

Com Eurifáessa, que lhe gerou três crianças formosas: Éos, a de braços rosados, Selene de belos cabelos,

E Hélios que nunca se cansa, semelho na forma aos eternos. Ele fulgura pros homens e para os eternos divinos Sobre seu carro, com olhos pungentes mirando através Do elmo dourado e emitindo a partir de si próprio brilhantes Raios que a todos deslumbram. Seus cachos fulgentes emoldam Graciosamente os dois lados de um rosto que brilha de muito Longe. Cintila por cima do corpo uma veste bonita, Bem trabalhada, que voa no vento. Corcéis o carregam. Logo detém seus cavalos e o carro de jugo dourado E sobre o ponto mais alto do céu ele tem seu descanso, Para em seguida descer pro Oceano de modo espantoso. Salve, senhor! De bom grado concede o que alegra esta vida! Tendo iniciado por ti, louvarei ora os semi-divinos, Cujas façanhas as deusas mostraram pros homens mortais. 


\section{Hino Homérico 32, a Selene}

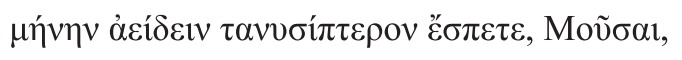

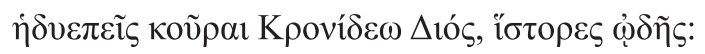

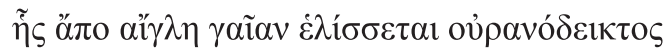

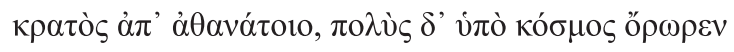

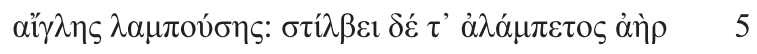

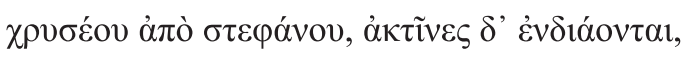

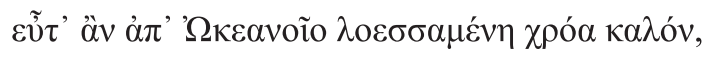

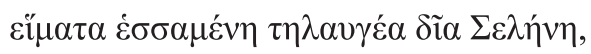

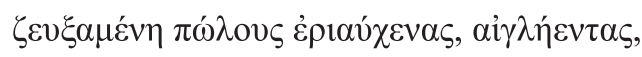

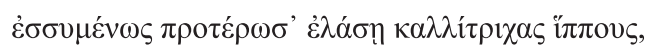

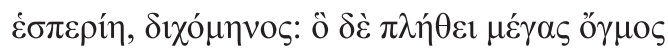

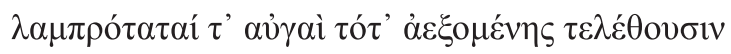

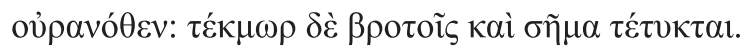

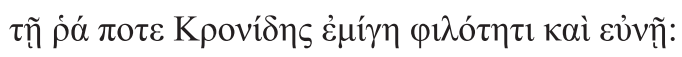
ๆे $\delta$ ' vं

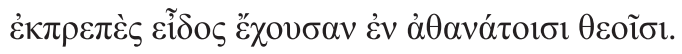

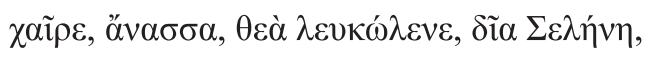

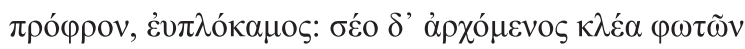

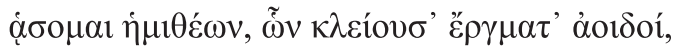

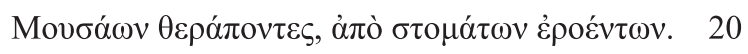

Musas, cantai a respeito da lua e suas asas compridas, Filhas de Zeus, do Cronida, versadas nas artes do canto. De seu semblante imortal lá no céu vem pra terra o seu brilho, Feito um enlace e do brilho esplendente uma enorme harmonia Faz-se presente. Reluz, mesmo estando sem luz há um momento $\mathrm{O}$ ar a partir de sua láurea dourada e seus raios fulguram Sempre que, tendo banhado seu corpo bonito no Oceano, Põe suas vestes que brilham de longe a divina Selene $\mathrm{E}$ após jungir os seus potros de fortes pescoços, brilhantes, 10 Corre adiante com seus animais de crineiras compridas No entardecer à metade do mês: é o momento em que está Cheia a sua órbita e então ela brilha mais forte ao crescer No alto do céu, um sinal confiável pros homens mortais. Foi certa vez ao seu leito o Cronida pra unir-se em amor, Ao que ela então concebeu e gerou uma filha, Pandeia, Que sempre excele entre os deuses eternos na forma adorável. Salve, senhora, divina Selene de cândidos braços, Acolhedora de belos cabelos! Agora te deixo Para cantar sobre a glória dos semi-divinos, honrados Pelos seus feitos nos lábios amáveis dos servos das Musas.

\section{Hino Homérico 33, aos Dióscuros}

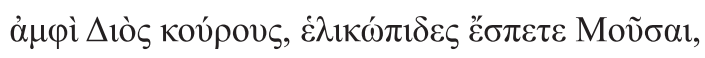

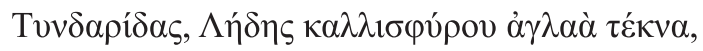

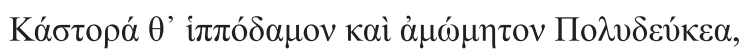

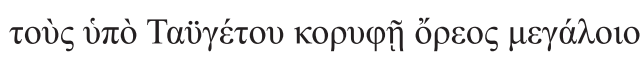

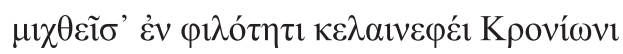

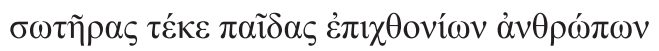

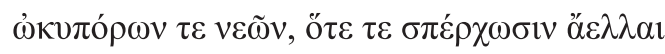

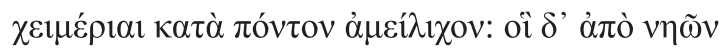

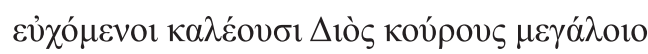

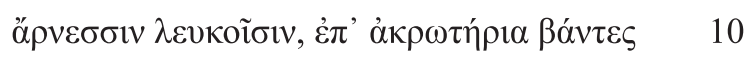

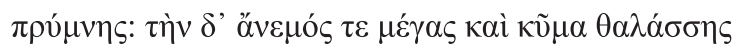

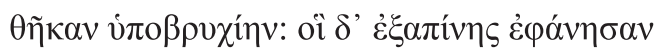

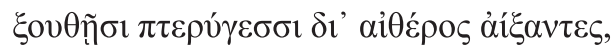

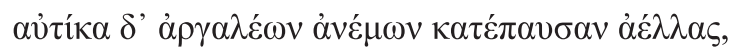

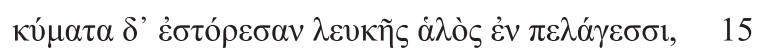

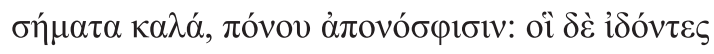

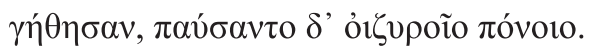

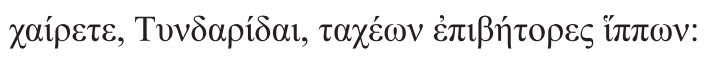
$\alpha$
Musas de vívidos olhos, cantai-me os dois filhos de Zeus, Prole brilhante de Leda dos pés adoráveis, Tindáridas, Cástor que doma cavalos e Pólux irrepreensível.

Tendo se unido em amor ao Cronida de nuvens escuras, 5 Ela os gerou sob os picos do monte Taígeto ingente, Filhos que salvam os homens terrestres nos barcos velozes Quando se agitam os ventos ao longo do mar implacável Ao despontar da borrasca, pois esse é o momento em que os nautas Chamam os filhos de Zeus grandioso, fazendo-lhes votos De alvos carneiros se pondo na parte mais alta da proa. Mas uma enorme lufada em conjunto com ondas marinhas Põe o navio sob a água. Eis que súbito surgem os dois Com suas asas velozes movendo-se em meio ao ar. Rapidamente interrompem os ventos penosos da chuva, Bem como as ondas, que pausam na vasta brancura do mar. Belos sinais eles são e das penas, o alívio. Ao vê-los, Todos se alegram e alcançam descanso da pena dorida. Salve, Tindáridas, ágeis ginetes de vossos cavalos! Ora de vós eu irei me lembrar e de uma outra canção. 


\section{Bibliografia}

ANTUNES, C. Leonardo B. Ritmo e Sonoridade na Poesia Grega Antiga: uma tradução comentada de 23 poemas. São Paulo: Humanitas, 2011.

EVELYN-WHITE, Hugh G. Hesiod, the Homeric Hymns and Homerica. Cambridge \& London: Harvard University Press \& William Heinemann Ltd., 1914.

GONÇALVES, Rodrigo Tadeu. "L'hexamètre au Brésil: la tradition de Carlos Alberto Nunes". Anabases (Toulouse), v. 20, p. 151-164, 2014.

HOMERO. Ilíada. Tradução de Carlos Alberto Nunes. Rio de Janeiro: Ediouro, 2001.

. Odisséia. Tradução de Carlos Alberto Nunes. Rio de Janeiro: Ediouro, 2001.

TÁPIA, Marcelo. Diferentes percursos de tradução da épica homérica como paradigmas metodológicos de recriação poética. Tese inédita. São Paulo: USP, 2012. 